PAEDAGOGIA ChristianA

2/24 (2009) - ISSN 1505-6872

Witold Starnawski*

Warszawa

\title{
Matka głupich? Filozoficzne aspekty nadziei
}

„[...] głupi i ludzie, którzy nie posługują się rozwagą, do wszystkiego się porywają i są pełni nadziei" ${ }^{\prime}$ - te słowa św. Tomasza z Akwinu stanowią usprawiedliwienie przywołania $\mathrm{w}$ tytule tego niechlubnego i niesprawiedliwego określenia, jakim niektórzy nazywają nadzieję. Wypowiedź św. Tomasza wzięta jest z artykułu Summy teologicznej zatytułowanego: Czy młodość i pijaństwo jest przyczynq nadziei? Nie sposób przejść obojętnie obok tego niepokojącego sygnału odsłaniającego ułomność nadziei czy też wskazującego jaką́ fałszywą jej postać. Także doświadczenie życiowe mówi, że nadzieja nie tylko bywa zawodna, ale zwodnicza; może być przeciwstawiana poczuciu rzeczywistości i zmysłowi krytycznemu. Głównym zadaniem tego tekstu jest próba odpowiedzi na pytanie - jakie są podstawy używania w sposób uzasadniony zwrotu „mam nadzieję”? Trzeba zatem przyjrzeć się również i tej nadziei, która z niepokojącą łatwością bywa używana do rozwiązywania problemów; określają ją zwroty: „mam nadzieję, że będzie dobrze” lub: „wszystko jakoś się ułoży”. Czy mocne pragnienie, aby stało się tak jak chcemy, jest wystarczające, aby ze spokojem myśleć o przyszłości? Przecież nadzieja może również łudzić, przesłaniać rzeczywistość, kiedy zaś runie misterna konstrukcja oparta na marzeniach i pragnieniach, może pociagnąć za sobą w otchłań tego, kto powierzył jej swą przyszłość. Złudnej nadziei można się również obawiać.

Zwykle o nadziei mówi się z perspektywy teologicznej. Tradycja chrześcijańska nazywa ją cnotą teologiczną. Nie kwestionując tej perspektywy, chcę mó-

* Dr Witold Starnawski, adiunkt na Wydziale Nauk Pedagogicznych Uniwersytetu Kardynała Stefana Wyszyńskiego w Warszawie.

${ }^{1}$ Summa teologiczna I-II, q. 40, 6. Teksty św. Tomasza podaję za polskim thumaczeniem Sumy teologicznej w przekładzie i opracowaniu P. Bełcha OP, F. W Bednarskiego OP, wydawanym systematycznie w Londynie przez Katolicki Ośrodek Wydawniczy „Veritas”. 
wić o nadziei w ludzkim doświadczeniu z perspektywy filozoficznej. Czy opierając się tylko na rozumie i doświadczeniu można dostrzec wartość nadziei? Dodać trzeba, że chodzi o taki rozum, który zna własne ograniczenia i nie ucieka przed tajemnica, i takie doświadczenie, które chce ogarnać każdy skrawek rzeczywistości, nie jest uprzedzone wobec rozumu. Mamy zatem do rozstrzygnięcia dwie kwestie:

1. Czy istnieją kryteria pozwalające odróżnić dwie postacie nadziei - tę, która odsłania rzeczywistość i tę, która zwodzi?

2. Czy doświadczenie człowieka, rozpatrywane w kategoriach naturalnych, filozoficznych, może nas doprowadzić do odkrycia i zrozumienia nadziei? Czy w przypadku nadziei możemy iść drogą podobną do tej, na której odkrywa się miłość, a więc przyjąć, że od jej słabych, niewyraźnych postaci, obecnych w ludzkim doświadczeniu (miłości dziecięcej, macierzyńskiej, ojcowskiej, przyjacielskiej, oblubieńczej), wiedzie droga do rozumienia samej miłości? Czy też należy uznać, że warunkiem nadziei jest wiara religijna, uznanie istnienia Boga jako fundamentu wszelkiej nadziei?

Odpowiedzi na tak postawione pytania spróbuję poszukać, odwołując się do myśli św. Tomasza z Akwinu, Jana Pawła II, Romana Ingardena, i przede wszystkim Gabriela Marcela².

\section{Czym jest nadzieja?}

Najpierw jednak bliżej określmy to, czego szukamy. Tomasz definiuje nadzieję poprzez charakterystykę jej przedmiotu. Jest nim po pierwsze dobro, po drugie jest to dobro przyszłe, po trzecie - wznosie i trudne do osiagnięcia, wreszcie - możliwe do zdobycia ${ }^{3}$. Nie chodzi tu o logiczną możliwość, lecz o coś więcej, to jest przekonanie (wiarę?) o jego realnej dostępności. W cytowanym wcześniej tekście św. Tomasz w odpowiedzi na jeden z zarzutów pisze: „Chociaż młodym i pijanym naprawdę brak siły, myślą jednak, że są mocni, gdyż nie znają swych braków"4. Logika tego wywodu zawiera sugestię, że nadziei towarzyszy świadomość braku. Można powiedzieć, że towarzyszy jej lęk: przed utratą dobra, które posiada, bądź obawa, że nie zdoła osiagnąć tego, czego pragnie. Lęk ten jest trwałym składnikiem nadziei, lecz nie przesłania jej, to ona dominuje, zawiera

${ }^{2}$ W przypadku św. Tomasza chodzi o teksty poświęcone nadziei zawarte w Summie teologicznej oraz streszczenie tej nauki w Katolickiej etyce wychowawczej o. Jacka Woronieckiego (Lublin 1986); w przypadku Jana Pawła II jest to tekst Problem konstytuowania się kultury poprzez ludzkq praxis, odnośnie Romana Ingardena jest to rozprawka Człowiek i czas. Sięgam również do znanego tekstu Gabriela Marcela Homo viator. Wstęp do metafizyki nadziei; może nie bez znaczenia jest fakt, że zaczerpnięty stamtąd tekst Zarys fenomenologii i metafizyki nadziei powstał w $1942 \mathrm{r}$.

${ }^{3}$ Summa teologiczna I-II, q. 40, 1.

${ }^{4}$ Tamże. 
się w niej przekonanie (pewność?), że dobro jest osiągalne mimo przeszkód, lęk pozostaje więc niejako w cieniu. Ten swoisty „optymizm” wewnętrznego nastawienia odróżnia nadzieję od zwykłego przewidywania kierującego się kalkulacją. Nadzieja nie opiera się na wyliczeniu prawdopodobieństwa. Czerpie swoją pewność ,skądinąd” - tylko skąd, oto jest pytanie.

Trzeba także zwrócić uwagę na inny ważny rys nadziei - jest nim odniesienie do czasu. Dotyczy ona „dobra przyszłego”, można więc powiedzieć, że jej żywiołem jest przyszłość. Jednak niezupełnie. Nadzieja żyje bowiem w teraźniejszości, przyszłość właściwie ją anuluje - nie potrzeba nadziei, skoro ,już wiadomo”, jak jest. Właściwą pozycją egzystencjalną nadziei zdaje się „być przyszłością w teraźniejszości”. Ona już „teraz” coś pokazuje, zapewnia, gwarantuje, mówi o czymś, co spełni się dopiero ,potem”. W pewien sposób ,przepowiada przyszłość”. Czy to jednak jest w ogóle możliwe? Czy przyszłość w jakikolwiek sposób może być w teraźniejszości obecna?

Z pozoru może się wydawać, że roszczenia do powiedzenia czegoś o przyszłości - i to w sposób pewny, bo nadzieja musi posiadać właściwą sobie pewność - są irracjonalne, co najwyżej można przenieść je do porządku nadnaturalnego. Sprawa nie jest jednak tak oczywista, jeśli rozważymy, czym właściwie jest przeszłość i przyszłość wobec teraźniejszości. Roman Ingarden w znanej rozprawce Człowiek $i$ czas ${ }^{5}$ przywołuje dwa doświadczenia czasu. W jednym z nich ,znajdujemy się jakby na ostrzu noża między dwiema otchłaniami niebytu: tego, czego już nie ma, i tego, co jeszcze nie istnieje"6. Czy jednak teraźniejszość jest tylko „punktowym teraz”, a przeszłość i przyszłość są wyłącznie otchłanią niebytu? Czy teraźniejszość nie żyje przeszłością? Drugie doświadczenie czasu, przeciwstawne pierwszemu, pokazuje, że to, co minęło i to, co nastapi, istnieje w pewien sposób w teraźniejszości. Przeszłość istnieje w postaci moich dawnych przyrzeczeń i zobowiązań, ale także wspomnień, win, klęsk i sukcesów. To, co się wydarzyło, „ciąży nad moją teraźniejszością” - jak pisze Ingarden. Ale dotyczy to również przyszłości: „[...] teraźniejszość moja stoi pod wpływem zapowiadającej się w jakikolwiek sposób przyszłości. To, co przyszłe, i to nieraz właśnie wtedy, gdy nie zależy ode mnie, wpływa na mnie już t e r a z i może mnie przekształcać. To, co przyszłe (lepiej: przyszłość moja), już jakby teraz j e s t, choć jeszcze nie jest samo obecne, lecz tylko «czeka» mnie lub na mnie"7.

Na razie możemy poprzestać na wniosku, że skoro przyszłość może oddziaływać na teraźniejszość, to znaczy, że w pewien sposób istnieje już teraz. Jeśli zwrócimy uwagę, że istnieje ona „w pewien sposób”, nie zaś aktualnie, tak jak teraźniejszość, wówczas wysnucie takiego wniosku nie będzie przejawem myślenia irracjonalnego.

\footnotetext{
5 R. Ingarden, Człowiek i czas, w: Ksiqżeczka o człowieku, Kraków 1975, s. 41-74.

6 Tamże, s. 53.

7 Tamże, s. 50-51.
} 


\section{Kryterium prawdziwej i złudnej nadziei}

Powróćmy do sprawy nadziei. Trudno wyobrazić sobie życie człowieka pozbawionego zupełnie nadziei. To tak, jak gdyby odebrano mu przyszłość, a tym samym - już teraz - siłę życiową. Bez-nadzieja jest złem, nic więc dziwnego, że człowiek, niemal instynktownie, a czasem zupełnie świadomie, chce się zabezpieczyć przed pustką, którą niesie ze sobą brak nadziei. Czy jednak sens nadziei można ograniczyć do tego tylko, aby chroniła przed pustką, czy nadzieja, sama w sobie, nie jest czymś pozytywnym i jest skazana wyłącznie na to, aby przykryć nicość przyszłości? Przyznajmy, że czasem tak bywa. Czyni tak ten, kto chce „zabić czas”, aby nie myśleć o tym, co przykre, oszukując się, że wszystko ,samo jakoś się ułoży". Taką fałszywą nadzieję - wiedząc o tym, że jest to czek bez pokrycia - podsuwa np. człowiek, który z grzeczności, ale również z obawy, aby nie obarczono go ciężarem współuczestnictwa w cierpieniu, mówi, że „,będzie dobrze", ukrywając przed chorym i przed sobą okrutną diagnozę lekarzy.

$Z$ jednej strony mamy więc nadzieję złudną i tanią. Złudną, bo opartą nie na prawdzie, ale i tanią, gdyż wytworzenie takiej wizji dobra, które w każdej chwili jest w zasięgu ręki, niewiele kosztuje. Spotykamy więc ludzi, którzy obdarzają taką tanią nadzieją, każdy problem potrafią rozwiązać... w przyszłości (a raczej to przyszłość ma go ,jakoś” rozwiązać), pocieszą, usuwając trudności... z pola widzenia. Taki obraz dominuje w wielu dziedzinach życia, w których należy być miłym i uśmiechniętym, nietaktem jest mówić o czymś zbyt serio czy roztrząsać poważne problemy. Można rozmawiać, słuchać, udzielać rad, ale wszystko to czyni się „na niby”, ani ten, kto pociesza, ani ten, kto wysłuchuje pocieszeń, nie bierze ich poważnie, inflacja nadziei jest tu wprost proporcjonalna do dewaluacji słowa.

Taka nadzieja niewiele warta, zamknięta $\mathrm{w}$ ramach konwencji, jest jednak groźna - zabija bowiem prawdziwą nadzieję, zagłusza ją, odbiera jej to, co najcenniejsze - wiarygodność. Znamienne jest to, że np. w świecie mediów, rozrywki czy polityki taka złudna nadzieja koegzystuje ze swoim przeciwieństwem, a więc z wizją świata, w którym triumfuje zło, przemoc i pustka. Obydwa światy - jeden: świat sztucznych uśmiechów, miłego nastroju, dobrego tonu, i drugi: brutalnie pokazujący, rzekomo prawdziwą, rzeczywistość okrucieństwa, bezwzględności, cynizmu - mają bowiem wspólną podstawę. Jest nią odrzucenie prawdziwej nadziei - w jednym króluje jej marna namiastka, w drugiej - rozpacz.

Docieramy do punktu, w którym coraz wyraźniej widać związek nadziei z prawda, co pogłębia znaczenie zwrotu ,prawdziwa nadzieja”. Odsłania rów-

${ }^{8} \mathrm{O}$ człowieku zagrożonym przemijaniem i niewiadomą nicością jutra Ingarden pisze tak: „ «Zabija czas»: wynajduje zajęcia, którymi by «wypełnił» czas, i całą uwagę swą koncentruje na robocie, bez której mógłby się obejść. [...] Zamiast b y ć przez pozostanie przy sobie, przez uchwycenie siebie w każdym bólu i w każdej radości, i w każdym wysiłku i zwycięstwie, zatraca się bezpowrotnie". Tamże, s. 65 . 
nież niebezpieczne związki nadziei z pragnieniem i marzeniami. „Mieć nadzieję” może bowiem znaczyć pragnać czegoś lub marzyć o czymś. Ktoś może marzyć o karierze, własnym domu, ale w tym znaczeniu, w jakim te przedmioty marzenia pozostają wyłącznie produktami psychiki, wyrazem emocji, niszczą prawdziwą nadzieję. Wyobraźnia, jeśli uznamy, że jest tworzeniem pewnej nierzeczywistości, nie da się pogodzić z nadzieją: wyobraźnia „więzi” nadzieję, a ta „rozrywa” wyobraźnię. Oto np. człowiek, który stoi na progu ważnych zmian w swoim życiu: ożenił się, został ojcem, zaczyna nową pracę i „,ma nadzieję”, że dobrze potoczy się to, co rozpoczyna. W pewien sposób wyobraża sobie swoją przyszłość: co będzie robił, jak będzie się zachowywał, co będzie sprawiało mu przyjemność, na jakie trudności natrafi - tworzy pewien obraz. Nie może jednak swojej przyszłości powierzyć takim tworom wyobraźni, nawet gdyby przybrały one postać „planów” i „projektów”; rzeczywistość nie zważa bowiem na nasze wyobrażenia i rozbija je w proch. Nadzieja musi czerpać z rzeczywistości, aby zachować swą moc, wyobraźnia odwraca od niej, dla nadziei znalezienie się w świecie wyobrażonym oznacza unicestwienie. Bywa, że młody człowiek syci się wyłącznie marzeniami o swojej przyszłości, lecz kiedy ich czar pryśnie, a on sam ochłonie, dostrzega różnicę między złudnością marzeń a realnością „,proroctwa nadziei”.

Warto zwrócić uwagę, że ten, kto utracił nadzieję, czuje się oszukany, okłamany - czy już to nie wskazuje, że w nadziei zawarte jest roszczenie prawdziwości (kto jednak miałby go okłamać lub oszukać, to osobne pytanie).

Nadzieja nie boi się rzeczywistości. Ukazanie zła, odsłonięcie szorstkiej materii prawdy, usuwanie zwodniczych zasłon nie musi naruszyć nadziei. Jest ona jak forteca obronna, która swoją przydatność może wykazać tylko wówczas, kiedy zostanie wystawiona na ciężką próbę. Jest wiele warta, kiedy zdoła obronić się przed wieloma przeciwnościami, nie ulegnie, nie przemieni się w rozpacz, nie stanie się beznadzieją.

\section{Czy nadzieja może być niezawodna?}

Jaka jest podstawa tej niezawodności? Przecież jednym z fundamentów myślenia racjonalnego jest nieprzewidywalność przyszłości. Owszem, można sądzić, że coś wydarzy się z pewnym, być może bardzo dużym prawdopodobieństwem, lecz w tym przypadku nie chodzi o probabilizm. Gdyby ktoś chciał opierać moc nadziei na rachunku prawdopodobieństwa, zniszczyłby jej osobowe oblicze. Spojrzenie nadziei nie jest nigdy spojrzeniem krytycznego, nieuczestniczącego w wydarzeniu obserwatora. Nie dotyczy ona dziedziny faktów. Dotyczy przyszłości, jednak nie jest jej przewidywaniem. Co więcej, Marcel podkreśla i wypada się zgodzić z takim odczytaniem zawartości ludzkiego doświadczenia - że przypadki przeciwne nadziei nie muszą wcale jej burzyć ${ }^{9}$. Można np. pokła-

9 Por. G. Marcel, Homo viator, Warszawa 1984, s. 65-66. 
dać nadzieję w miłości mimo tego, że wydaje się z każdym dniem coraz bardziej przegrana. Można zachować nadzieję, widząc triumf zła i można w niej trwać, mimo „powszechnej opinii”, że nic się nie zmieni i mimo braku „obiektywnych podstaw” do takiej zmiany (choć oczywiście należałoby zapytać, kto zna „obiektywne kryteria”, które gwarantują to, co „wydarzy się” w przyszłości?). Wciąż jednak zachowuje swą ważność pytanie: jak odróżnić w takich przypadkach drogę głupca od drogi człowieka nadziei?

Marcel zwraca uwagę, że nadzieja pojawia się w postaci wewnętrznego przeżycia czy raczej postawy, dla której charakterystyczne jest to, iż jest nieobojętna dla podmiotu. Właściwym przejawem nadziei jest to, co „mi leży na sercu". Opiera się zatem na rozpoznaniu prawdy, żyje nią, lecz sięga dalej, ponad aktualne poznanie. Obca jest jej właściwa dla poznania postawa bierności. Nadzieja, co podkreśla także św. Tomasz, jest przejawem woli. Marcel, nawiązując do znanego rozróżnienia między „wierzę” (,wierzę komuś”) a „wierzę, że”, wprowadza analogicznie rozróżnienie między „mam nadzieję” a „mam nadzieję, że" ${ }^{10}$. W pierwszym przypadku chodzi o wewnętrzne nastawienie skupione na rzeczywistości; nie jest ona przedmiotem zewnętrznym wobec mnie, lecz jestem w nią włączony, żyję nią. To, co w niej spotykam, nie jest w terminologii Marcela „problemem”, lecz „tajemnica”". Nie chodzi jednak o „wtajemniczenie”, dopuszczenie do grona „oświeconych”, którzy mogą zajrzeć za kotarę przyszłości. Chodzi raczej o pokorne, nieśmiałe, choć stanowcze przekonanie, że jakakolwiek sytuacja zła, lęku, zniewolenia nie jest ostateczna. Druga postawa „mam nadzieję, że" oznacza złudne przeświadczenie, że można przeniknąć tajemnice przyszłości i już dziś stwierdzić, „co się stanie”, jak rozstrzygnie się konkretna sprawa: czy zdoła się pokonać konkretną przeszkodę, czy choroba ustąpi, czy przyjdzie upragnione zwycięstwo? W tej drugiej postawie oparciem dla nadziei jest skuteczne przewidywanie przyszłości.

Nadzieja nie opiera się jednak na paranormalnym poznaniu tego, co będzie, nie wydziera przyszłości jej tajemnic. Przywołanie przyszłości odbywać się może na zasadzie wyobrażenia jak będzie, lecz nasze doświadczenie mówi nam, że rzeczywistość, która nadchodzi, jest zupełnie czymś innym niż wyobrażenia o niej. Wyobraźnia kłamie, jeśli chce udawać rzeczywistość (nikt nie chce mieć w przyszłości „wyobrażonego domu”, lecz „dom prawdziwy”; tego, kto szuka miłości, nie zadowoli, że znajdzie ją w swoich marzeniach). Marcel przytacza zarzut, który nadziei stawia krytyczny rozum (w znaczeniu - ciasno krytykancki): nadzieja nie jest niczym innym jak tylko racjonalizacją naszych gorących pragnień; do jej istoty należy więc złudzenie. I odpowiada: „im bardziej nadzieja przewyższa moją wyobraźnię, tak że nawet zakazuję sobie wyobrażania tego, co jest przedmiotem mojej nadziei, tym skuteczniej, jak się wydaje, ów zarzut może być odparty"11.

\footnotetext{
10 Tamże, s. 33.

11 Tamże, s. 46.
} 
Nie jest to jeszcze odpowiedź na zarzut, raczej jej zapowiedź i wskazanie, którą drogą podążać nie należy. Gdzie zatem należy szukać jej metafizycznych podstaw?

\section{Nadzieja jako postać wolności}

Paradoks nadziei polega na tym, że nie rozgrywa się ona wyłącznie w wewnętrznej (a tym bardziej - psychicznej) rzeczywistości człowieka, dotyczy tego, co od człowieka niezależne. Z drugiej jednak strony odsłania związek człowieka ze światem, ujawnia, że człowiek w nim współuczestniczy za sprawą swojej wolności. Nadzieja całą swoją mocą przeciwstawia się temu, co miałoby być „ostatecznie przesądzone”. Nie ma dla niej miejsca w świecie, w którym istnieje bezwzględna konieczność. Warunkiem istnienia nadziei jest to, by świat nie był jednoznacznie zdeterminowany. Nie ma nadziei bez wolności. I to takiej, która jest siłą twórczą i tym samym odsłania twórczy charakter rzeczywistości. Ta zaś nie jest skończona, zamknięta - przeciwnie jest nieodgadniona - nie dlatego, że umysł ludzki nie potrafi przeniknąć przyszłości, ale dlatego, że zawiera w sobie pierwiastek nieokreśloności związany z wolnością. Jeśli człowiek nie potrafi powiedzieć, co będzie jutro, czy rzeczywistość potwierdzi jego przypuszczenia, to właśnie dlatego, że jutro jest zaws ze inne niż to, co można o nim pomyśleć dziś - to wolne osoby niosą losy świata. Nadzieja odwołuje się do tej wolności, w niej pokłada swoją nadzieję. Świat, który byłby „mechanizmem”, a więc byłby jednoznacznie zdeterminowany odgórnie lub „oddolnie” (na przykład podlegałby wyłącznie bezdusznym działaniom jakichś sił, kosmosu itp.), byłby światem okrutnym, pustym, beznadziejnym. Niektórzy tak właśnie wyobrażają sobie wszechmoc Boga - jako Tego, który odwiecznie zaplanował świat i teraz realizuje ten plan, nie zważając na wolę osób, które powołał do istnienia. Doświadczenie człowieka przeczy jednak determinizmowi.

Przy takim spojrzeniu można zrozumieć, dlaczego nadzieja nie upada mimo przeciwności. Jest bowiem nie tylko odczytywaniem dobra, które się wydarzy, ale również jego współtworzeniem. Jest czynnikiem aktywnym, wolą dobra, która oparta jest na dobru już istniejącym i na rozpoznaniu prawdy w jej najgłębszych korzeniach - tam, gdzie prawda jednoczy się z dobrem. Nie można przecenić z tego punktu widzenia odkrycia metafizyki, że byt w swych podstawach jest dobry $z$ racji istnienia (transcendentalne dobro). Nadzieja może czerpać swój metafizyczny optymizm z faktu, że zadaniem wolności jest aktualizacja dobra, wprowadzanie go do pełnej bytowości.

Zadaniem wolności jest więc zmieniać świat, aktualizować istniejące w nim dobro. Nie ma to nic wspólnego z samowolą uzurpującą sobie prawo władania światem. Jest w tym również zawarty sprzeciw wobec wolności ograniczającej się wyłącznie do władania sobą. „Świat mnie nie interesuje, na innych ludzi nie mam wpływu, mogę tylko zmienić siebie, sobie samemu panować - powinie- 
nem więc skupić się tylko na sobie, gdyż to jest najbardziej efektywne, jedynie rzeczywiste pole mojej wolności" - taka wizja wolności jest zacieśnieniem, subiektywizacją, płynie z lęku przed światem, z obawy przed roszczeniami innych, chce pielęgnować wyłącznie własne poletko. Właściwie nie ma tu miejsca na nadzieję - ta bowiem jest ryzykiem i wyzwaniem rzuconym światu. Prawdziwa nadzieja jest nieustraszona, choć łagodna, nieugięta, a zarazem gotowa przyjąć to, co się wydarzy. Realizm spojrzenia łączy z otwartością na to, co nieprzewidywalne, a taka postawa może być czasem, niesłusznie, uznana za niefrasobliwa, choć w rzeczywistości jest ,,powierzeniem przyszłości tego, co przyszłe”. Jej wyrazem jest np. zachowanie św. Teresy z Avilla. Zbudzona w nocy przez zalęknioną siostrę pytaniem: „Matko, gdybym teraz tu nagle umarła, co byś ty wówczas sama jedna poczęła?” - odparła: „Jak się to stanie, siostro, pomyślę, co zrobić. Tymczasem daj mi spać"12.

\section{Ostateczny przeciwnik - śmierć}

To, co powiedzieliśmy do tej pory, jest naznaczone poważna ułomnością. Nadzieja może liczyć, że jakieś ,,potem” odmieni los, przyniesie upragnione rozwiązanie, co jednak, gdy bieg wydarzeń zostanie nieuchronnie przerwany? Z perspektywy doczesności kresem ludzkich dążeń jest śmierć. Zdaje się ona niszczyć ludzkie nadzieje, odziera je z mocy, pokazuje, że nie ma już żadnego ,potem”, w którym los mógłby przynieść odmianę.

Śmierć, nie rozpacz (z tej bowiem można się uwolnić), jest zatem właściwym przeciwnikiem nadziei. Czy jest jednak przeciwnikiem ostatecznym i zawsze zwycięskim? Przywołanie śmierci - kresu doczesnego życia człowieka, poza elementem nieuchronności i grozy - pozwala odsłonić jeden ważny aspekt. Chwytamy coś, co pozwala zobiektywizować problem nadziei, wyzwolić go z uwikłania w subiektywizm chęci i pragnień, odsuwa na bok jałowy język prawdopodobieństwa. Śmierć jest jedynym pewnym faktem z przyszłości, którego nie sposób zakwestionować. Jest czymś wpisanym w kondycję człowieka, a więc istnieje, choć dopiero nadejdzie. W paradoksalny sposób jest ona tym, co może nadziei zapewnić obiektywność i tę poszukiwaną niezawodność - pod warunkiem, że zostanie zwyciężona. Jak w dziecięcej baśni, gdzie jedynym warunkiem przemiany złowrogiego losu i zwycięstwa dobra na zawsze jest pokonanie smoka lub okrutnego czarnoksiężnika - stoczenie z nim walki na śmierć i życie.

Czy człowiek jest z góry skazany w tej walce na porażkę? Sięgnijmy raz jeszcze do Ingardena. Pisze on: „Istnieją swobodne i odpowiedzialne czyny moje, które spełniam w ciężkich chwilach życia - czasem w obliczu śmierci - a które biją z najgłębszego wnętrza mego «ja» [...] a czas, mimo wszelkich zmian, jakie we mnie wywołuje, nie może mi nic zrobić, jest wobec mej najgłębszej istoty bez-

${ }^{12}$ E. Renault, Święta Teresa z Avila, Kraków 1983, s. 61. 
silny, spływa po mnie jak woda [...] W czynach takich przejawia się moje «ja», trwałość mego istnienia. Spełnienie ich zarazem w z m a g a moje siły, b u d u je «mię»na przyszłość, uniezależnia «mię»od czasu”lis. Ingarden nie rozstrzyga, jak naprawdę jest, choć nie są to tylko ontologiczne rozważania (a więc dotyczące tego, co możliwe), sugeruje, i to w sposób wyrazisty, kierunek, w którym należy szukać rozwiązania: „[...] jestem siłą, która sama siebie mnoży, sama siebie buduje i sama siebie przerasta [...] Trwać i być wolna może tylko wtedy, jeżeli siebie samą dobrowolnie odda na wytwarzanie dobra, piękna, prawdy. Wówczas dopiero istnieje"14.

Człowiek może więc przezwyciężać czas nie wtedy, kiedy „płynie” z jego biegiem, ale kiedy „trwa” niczym kamień, którego nie jest w stanie poruszyć rwący nurt rzeki. Tak podmiot - ,ja" może trwać w czasie, który przemija. Czy oznaczać to może „trwanie” nie tylko „w czasie”, ale i „ponad czasem”, tej kwestii Ingarden nie podejmuje. Możemy jednak już dostrzec światło. Jeśli śmierć jest przekreśleniem przyszłości i końcem czasu, to nie musi oznaczać końca takiego trwania, które zdoła wyzwolić się z czasu, uniezależnić od niego. W tym miejscu należałoby dopiero rozpoczać rozważania i zapytać, czy w ludzkim świecie można znaleźć takie „odłamki wieczności”, które - niczym opadłe na powierzchnię ziemi meteoryty - ujawniają swoje pochodzenie „nie z tego świata”. Czy nie jest nim niekiedy miłość, która zdolna jest przekraczać nieprzekraczalne bariery i obalać mury nie do obalenia? A może są to niektóre zasady moralne tak dziwaczne i niepraktyczne w ludzkim życiu jak ta, że nie wolno poświęcić życia jednego człowieka dla ratowania dziesięciu, stu, a nawet miliona ludzi? Takich „odłamków” można by szukać także w świecie tego, co piękne; nie tyle trwają one w czasie, co podważają istnienie czasu jako nieuchronnego przechodzenia przeszłości w przyszłość. Ten, kto je podniesie i uzna za swoje, prędzej czy później będzie musiał zapłacić za odnaleziony „skarb” - przyjdzie mu zmierzyć się z roszczeniami świata, którego zasadą jest przemijalność, zniszczenie, śmierć, nie ma w nim miejsca na nic wiecznego. Starcie to wydaje się nieuniknione, skoro śmierć zmierza $\mathrm{w}$ gruncie rzeczy do przekreślenia nieutylitarnej wartości dobra, trwałości zasad moralnych, nieprzemijalności tego, co piękne - chce uczynić wszystko przemijalnym, ważnym tylko „do czasu”. Konflikt nieubłaganie narasta, śmierć ma władzę nad ludzkim czasem i zdaje się triumfować, ale czy może zwyciężyć to, co wyłamuje się spod władzy czasu?

Podstawę ludzkiej nadziei, filozoficznie rzecz biorąc, stanowią akty transcendencji, które ,żąająa” trwałości przekraczającej czas, i tym samym zaświadczają o niej. I wydaje się, że tak sprawę widzi Marcel. Pisze on: ,[...] nadzieja jest $\mathrm{z}$ istoty swej jak gdyby gotowością duszy zaangażowanej dostatecznie głęboko w doświadczenie komunii, by mogła dokonać aktu transcendentnego,

${ }^{13}$ R. Ingarden, dz. cyt., s. 69-70.

${ }^{14}$ Tamże, s. 73-74. Ingarden w przypisie zaznacza, że zakończenie szkicu, z którego pochodzą przywołane cytaty, zostało dopisane w czasie wojny. 
odmiennego od aktu woli i poznania, którym to aktem stwierdza ona żywą wieczność; przy tym doświadczenie to stanowi jednocześnie rękojmię i przesłanki owej wieczności”'15.

Podobną myśl zwierają rozważania kardynała Karola Wojtyły na temat kultury nawiązujące do Norwidowskiego Promethidiona ${ }^{16}$. „Odłamków wieczności” można tu szukać w dziełach kultury, które zrodziły się z zachwytu i podziwu będącego owocem bezinteresownego obcowania z prawda, dobrem i pięknem. Kultura $\mathrm{z}$ tego punktu widzenia jest jakby walką ze śmiercia, polega na przekraczaniu tego, co tylko użyteczne (utile). To zmaganie dotyczy zarówno tego, kto tworzy, jak i tego, kto obcuje z kultura, w większym jednak stopniu twórcy. Wydobywa on i utrwala to, co „ponad-użyteczne”. W zobiektywizowanych dziełach kultury zawiera się ślad tego, czym żył on sam. „Umierając, ów konkretny człowiek zabrał ze sobą to, co było ściśle wewnętrzne i «nieprzechodnie» w całym jego działaniu, jednakże ślady, które pozostały w ludzkiej kulturze, nie tylko same opierają się śmierci, żyją bowiem i ożywiają coraz to nowych ludzi, ale ponadto zdają się wołać o nieśmiertelność, a może więcej: świadczyć o osobowej nieśmiertelności człowieka, właśnie z racji tego, co w nim «nieprzechodnie»" $" 17$.

„Pewność nadziei” powstaje jako rezultat zmagania ze śmiercią czy raczej z jej forpoczta, która tropi wszelkie najdrobniejsze przejawy tego, co wieczne. Do chwili „ostatecznego rozstrzygnięcia”, w którym nadzieja ma swój kres. Oznacza to zarazem, że do tego momentu nadzieja pozostaje dążeniem i walką, jej pewność zawiera zawsze znak zapytania, który w większym być może stopniu dotyczy nie tego, czy nadzieja się „spełni”, lecz czy człowiek zdoła w niej „wytrwać".

\section{Mother of the foolish? Philosophical aspects of a hope (Summary)}

This text focuses on the problem of hope in a philosophical aspect. It has been based on the thought of st. Thomas, Roman Ingarden, Karol, Wojtyła, and particularly Gabriel Marcel. The author concentrates on two questions: 1. Are there any criteria to distinguish between two forms of hope: the first - that reveals reality, second - that deludes. 2. Can the experience of men in terms of natural, philosophical categories lead us to discovering and understanding hope? „To be future in the present”- is the existential position of hope.

${ }^{15}$ G. Marcel, dz. cyt., s. 70 .

${ }^{16}$ K. Wojtyła, Problem konstytuowania się kultury poprzez ludzka praxis, „,Roczniki Filozoficzne" XXVII (1979), z. 1, s. 9-20.

17 Tamże, s. 19. 
It ought to be based on reality, not on desires or dreams. Hope means: no situation of evil or fear is ultimate. It is not the prediction of the future. Transcendental acts of men are philosophical basis of hope (Marcel, Wojtyła); they oppose everything, that passes away, ultimately - they oppose death. 